\title{
Thermal Behavior of Mg-Doped Calcium-Deficient Apatite and Stabilization of $\beta$ Tricalcium Phosphate
}

\author{
Asmaa Massit ${ }^{1}$, Ahmed El Yacoubi ${ }^{1}$, Abdellah Rezzouk ${ }^{2}$, Brahim Chafik El Idrissi ${ }^{1, *}$ \\ 1 Laboratoire des Matériaux avancés et de Génie des Procédé, Faculty of Sciences, Ibn Tofail University, Kenitra, \\ Morocco \\ 2 LPS, Fac. des Sciences Dhar El Mehraz, University Sidi Mohammed Ben Abdellah, BP 1796, Atlas FES, Morocco \\ * Correspondence: chidrissi@yahoo.fr;
}

Scopus Author ID 6602822327

Received: 30.04.2020; Revised: 24.05.2020; Accepted: 24.05.2020; Published: 27.05.2020

\begin{abstract}
TCP) is a bioceramic with unique osteoinductive and osteoconductive properties. It can be obtained by calcining calcium-deficient apatites $(\mathrm{CDHA})$ at $750^{\circ} \mathrm{C}$ and above. The reduction of calcining temperature or the stabilization of the $\beta$ phase, by doping, is therefore of particular interest. This paper investigates the preparation of CDHA with a theoretical 0.05 $\mathrm{Mg} /(\mathrm{Ca}+\mathrm{Mg})$ ratio and $(\mathrm{Ca}+\mathrm{Mg}) / \mathrm{P}=1.55$ via precipitation method, and the resultant powder is calcined at a different temperature ranging from 80 to $715^{\circ} \mathrm{C}$. The as-synthesized undoped powder was used as the reference in this study. The effect of calcination temperature and composition were investigated by the aid of X-ray diffraction (XRD), Fourier transform infrared spectroscopy (FTIR), inductively coupled plasma optical emission spectroscopy (ICP-OES) and scanning electron microscopy (SEM). The study indicated that the powder was pure Mg-doped beta-tricalcium phosphate. The incorporation of $\mathrm{Mg}$ within the calcium phosphate lattice promoted the formation and stabilization of the $\beta$-TCP phase at a lower temperature.
\end{abstract}

Keywords: Calcium-deficient apatite; $\beta$-tricalcium phosphate; $\mathrm{Mg}$ doping; Rietveld refinement.

(C) 2020 by the authors. This article is an open-access article distributed under the terms and conditions of the Creative Commons Attribution (CC BY) license (https://creativecommons.org/licenses/by/4.0/).

\section{Introduction}

$\beta$-TCP ( $\left.\beta-\mathrm{Ca}_{3}\left(\mathrm{PO}_{4}\right)_{2}\right)$ has been proved to have good biocompatibility. Its composition is similar to natural bone mineral components [1-3], it has found applications as bone cement and bone implant material. Besides, the biodegradation of $\beta$-TCP (solubility product, Ksp = $\left.1.25 \times 10^{-29}\right)$ is much better than other popular bioceramics, such as hydroxyapatite (Ksp = $2.35 \times 10^{-29}$ ), which is more advantageous in fitting the bone reconstruction cycle [4]. Substantial studies adopted the addition of functional ions to enhance the osteoinduction of calcium phosphate. It is well known that doping at even deficient levels can drastically affect the physical and morphological properties of different materials, including TCP [5,6]. The rhombohedral structure of $\beta$-TCP, space group R3c, it can host several ionic replacements, especially the replacement of calcium ions with divalent cations [7-13].

Magnesium $(\mathrm{Mg})$ is one of the most abundant ions in hard biological tissue, with a concentration of around 0.6 (wt\%) [14]. It has been reported that magnesium ions $\left(\mathrm{Mg}^{2+}\right)$ have an effect on bone metabolism, promoting new bone formation, and inducing a significant increase in osteogenic activity $[15,16]$. They also play a direct and essential role in maintaining vascular function $[17,18]$. Recently, this element, as a dopant in $\beta$-TCP, has been the subject of specific interest, due to its essential role in biological processes upon implantation $[19,20]$. 
In wet-chemical processes, $\beta$-TCP cannot be directly precipitated but can be transformed from a non-stoichiometric apatite, which has a molar ratio of $\mathrm{Ca} / \mathrm{P}$ ranging from 1.33 to 1.65 [21] during heat treatment. Non-stoichiometric apatite with the formula, $\mathrm{Ca}_{10-\mathrm{x}}\left(\mathrm{HPO}_{4}\right)_{\mathrm{x}}\left(\mathrm{PO}_{4}\right)_{6-\mathrm{x}}(\mathrm{OH})_{2-\mathrm{x}}(0 \leq \mathrm{x} \leq 1)$, has a crystal structure similar to the stoichiometric Hydroxyapatite (HA). Heat treatment is required for non-stoichiometric apatite to be transformed into HA and $\beta$-TCP according to Equation (1):

$\mathrm{Ca}_{10-\mathrm{x}}\left(\mathrm{HPO}_{4}\right)_{\mathrm{x}}\left(\mathrm{PO}_{4}\right)_{6-\mathrm{x}}(\mathrm{OH})_{2-\mathrm{x}} \rightarrow \mathrm{Ca}_{10}\left(\mathrm{PO}_{4}\right)_{6}(\mathrm{OH})_{2}+\beta-\mathrm{Ca}_{3}\left(\mathrm{PO}_{4}\right)_{2}+\mathrm{xH}_{2} \mathrm{O}$

when the $\mathrm{Ca} / \mathrm{P}$ molar ratio is 1.5 ( $\mathrm{x}=1$ in Equation (1)), Chemical transformation of CDHA to $\beta$-TCP via heat treatment can be described by Equation (2):

$$
\mathrm{Ca} 9\left(\mathrm{HPO}_{4}\right)\left(\mathrm{PO}_{4}\right)_{5}(\mathrm{OH}) \rightarrow 3 \mathrm{Ca}_{3}\left(\mathrm{PO}_{4}\right)_{2}+\mathrm{H}_{2} \mathrm{O}
$$

This methodology was adapted to form Mg stabilized $\beta$-TCP by introducing a precursor of $\mathrm{Mg}$ into the reaction system. The purpose of this study is to clarify the effect of $\mathrm{Mg}$ doping on the TCP structure through XRD and FTIR.

\section{Materials and Methods}

Calcium hydroxide $\left[\mathrm{Ca}(\mathrm{OH})_{2}\right]$ (Scharlau, Spain), magnesium chloride $\left[\mathrm{MgCl}_{2} \cdot 6 \mathrm{H}_{2} \mathrm{O}\right]$ (Riedel-de Haën, Germany) and orthophosphoric acid [ $\left.\mathrm{H}_{3} \mathrm{PO}_{4}\right]$ (Riedel-de Haën, 85\%) were used as starting materials for the synthesis of undoped $\beta$-TCP $(0 \mathrm{Mg})$ and $5 \mathrm{~mol} \%$ magnesiumdoped tricalcium phosphate $(5 \mathrm{Mg})$ with $\mathrm{Mg} /(\mathrm{Ca}+\mathrm{Mg})$ ratio equal to 0.05 according to the method described by A. Elouahliet et al. [22] with some modifications. Magnesium substituted calcium-deficient apatite (Mg-CDHA) with $\mathrm{Mg} /(\mathrm{Ca}+\mathrm{Mg})$ ratio equal to 0.05 was synthesized by precipitation method from an aqueous solution of $1.25 \mathrm{M}\left[\mathrm{Ca}(\mathrm{OH})_{2}\right], 2.85 \mathrm{M}\left[\mathrm{H}_{3} \mathrm{PO}_{4}\right]$ and magnesium chloride $\left[\mathrm{MgCl}_{2} \cdot 6 \mathrm{H}_{2} \mathrm{O}\right]$ at $40^{\circ} \mathrm{C}, \mathrm{pH}=9 . \mathrm{MgCl}_{2} \cdot 6 \mathrm{H}_{2} \mathrm{O}$ was added slowly to the continuously stirred solution of $\mathrm{Ca}(\mathrm{OH})_{2}$.

The aqueous solution of $\mathrm{H}_{3} \mathrm{PO}_{4}$ was added rapidly to the above solution containing calcium and Magnesium ions using a vigorous stirring. The nominal composition, $(\mathrm{Ca}+\mathrm{Mg}) / \mathrm{P}$ ratio, was maintained at 1.55 . For comparison, a $0 \mathrm{Mg}$ sample was obtained when $\mathrm{MgCl}_{2} \cdot 6 \mathrm{H}_{2} \mathrm{O}$ was absent. Precipitates were aged in mother liquors at room temperature for $24 \mathrm{~h}$, washed with distilled water, vacuum filtered, and finally dried $24 \mathrm{~h}$ in the oven at $80^{\circ} \mathrm{C}$ and coded as $0 \mathrm{Mg} 80$ and $5 \mathrm{Mg} 80$. The as dried $5 \mathrm{Mg} 80$ sample was subsequently subjected to different calcination temperatures 500,650 , and $715^{\circ} \mathrm{C}$ and coded as $5 \mathrm{Mg} 500,5 \mathrm{Mg} 650$, and $5 \mathrm{Mg} 715$, respectively.

The $0 \mathrm{Mg} 80$ sample was calcined at $850^{\circ} \mathrm{C}$ and coded as $0 \mathrm{Mg} 850$. Content of $\mathrm{Ca}, \mathrm{Mg}$, and $\mathrm{P}$ in the reaction product was quantified by the inductively coupled spectrometer (Shimadzu, ICP Spectrometer ICP-9000).

The crystalline phase composition was determined by X-ray powder diffraction (XRD) using a XPERT-PRO diffractometer working with $\mathrm{Cu} \mathrm{K \alpha}$ radiation at $40 \mathrm{kV}$ and $30 \mathrm{~mA}$; the measurement was carried out in the $2 \theta$ range of $10-70^{\circ}$, with the step of 0.017 and Scan Step Time 34(s). The data for XRD Rietveld refinement were collected under the same conditions. The characteristic functional groups of Mg-TCP were identified by Fourier transform infrared (FTIR) spectroscopy, VERTEX 70, Genesis Series (400-4000 $\mathrm{cm}^{-1}$, resolution 4, scans 20). For this, $1 \%$ of the powder was mixed and ground with $99 \% \mathrm{KBr}$, and the spectrum was taken in the range of 400 to $4000 \mathrm{~cm}^{-1}$.

The surface changes of samples ultrastructure and morphology were examined with a scanning electron microscope (ESEM, Quanta $200 \mathrm{FEI}$ ) at an operating voltage of $15 \mathrm{kV}$. 
Table 1. Magnesium content and $(\mathrm{Ca}+\mathrm{Mg}) / \mathrm{P}$ ratio of the synthesized powders, determined by ICP-OES and proposed chemical formula.

\begin{tabular}{c|c|c|c|c}
\hline Sample & $\begin{array}{c}\text { Nominal Mg } \\
\text { mol\% }\end{array}$ & $\begin{array}{c}\mathrm{Mg} /(\mathrm{Ca}+\mathrm{Mg}) \\
\mathrm{mol} \%\end{array}$ & $(\mathrm{Ca}+\mathrm{Mg}) / \mathrm{P}$ & Chemical formula \\
\hline $0 \mathrm{Mg} 80$ & 0 & 0 & 1.54 & $\mathrm{Ca} 9.24\left(\mathrm{HPO}_{4}\right)_{0.76}(\mathrm{PO} 4)_{5.24}(\mathrm{OH})_{1.24}$ \\
\hline $5 \mathrm{Mg} 80$ & 5.0 & 5.63 & 1.52 & $\mathrm{Ca} 8.95 \mathrm{Mg}_{0.17}\left(\mathrm{HPO}_{4}\right)_{0.88}(\mathrm{PO} 4)_{5.12}(\mathrm{OH})_{1.12}$ \\
\hline
\end{tabular}

\section{Results and Discussion}

\subsection{As-dried powders.}

0Mg80 and 5Mg80 powders were chemically analyzed by ICP-OES method. The results of the detailed analyzes are given in Table 1 . This gives a $\mathrm{Mg} /(\mathrm{Ca}+\mathrm{Mg})$ ratio of 0.0563 , which is slightly higher than the nominal ratio (based upon the amount of $\mathrm{Mg}$ in the precursor solution) of $(\mathrm{Mg} /(\mathrm{Ca}+\mathrm{Mg})=0.05)$ used for synthesizing the $5 \mathrm{Mg}$. Positive and negative deviations from the $(\mathrm{Ca}+\mathrm{Mg}) / \mathrm{P}=1.55$ ratio are observed for $0 \mathrm{Mg} 80$ and $5 \mathrm{Mg} 80$ samples, respectively. The Ca-deficient apatites used in this study had a $\mathrm{Ca} / \mathrm{P}$ ratio $>1.52$. According to Destainville et al. [23], heating, these CDHA could lead to the formation of a biphasic mixture of $\beta$-TCP and HA. Therefore, the expected products of the chosen reaction synthesis are expressed by the generic formula:

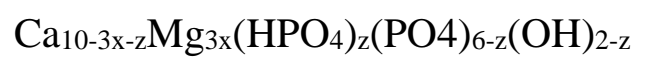

Where $0<\mathrm{z}<1$ corresponds to the amount of $\mathrm{HPO}_{4}{ }^{2-}$ groups. Therefore, $\mathrm{Mg}$ content expressed in mol\% is equal to $300 \mathrm{x} /(10-\mathrm{z})$, and $(\mathrm{Ca}+\mathrm{Mg}) / \mathrm{P}$ ratio is given by $(10-\mathrm{z}) / 6$.

Crystallite sizes determined from XRD data of samples, using the Scherrer formula for the peaks at $25.90^{\circ}$ and crystallinity degrees (Xc), are listed in Table 2, a decrease in both the crystallite size and $\mathrm{Xc}$ was observed when $\mathrm{Mg}$ was incorporated within apatite lattice. The presence of $\mathrm{Mg}^{2+}$ ions seems to make the crystallization more difficult. The XRD patterns for the as-dried powders are presented in fig. 1. The obtained XRD patterns of both undoped and doped-samples resemble that of CDHA (without a second phase) as from the perfect match with HA (\#09-0432 card) characteristic reflections. However, the $\mathrm{Ca} / \mathrm{P}$ molar ratio was not fixed at 1.67 .

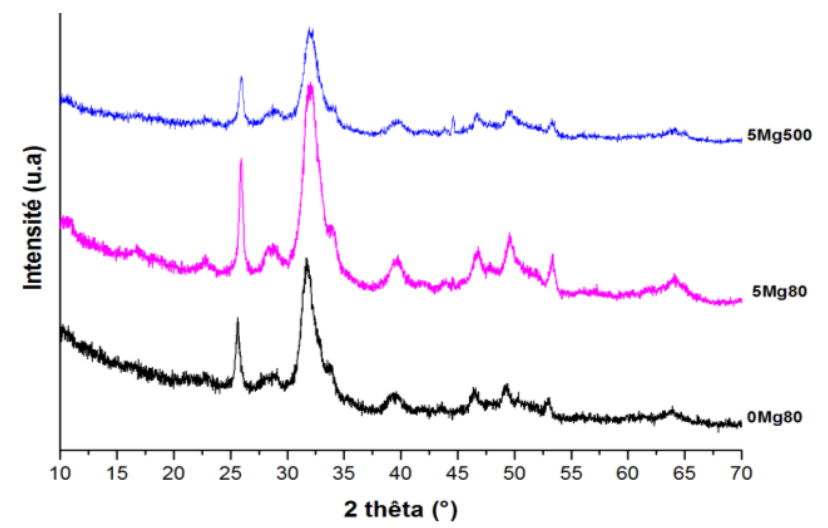

Figure 1. XRD patterns of $0 \mathrm{Mg} 80,5 \mathrm{Mg} 80$, and $5 \mathrm{Mg} 500$ samples.

All the as-dried powders had a low degree of crystallinity, as evidenced by XRD patterns with relatively broad and low-intensity XRD peaks, which were attributed to small crystallite size characteristics of the apatite phase. Moreover, due to the existence of $\mathrm{Mg}$, the diffraction peaks shifted to larger angles in the pattern, compared with undoped sample $(0 \mathrm{Mg} 80)$, resulting from the crystalline cell contraction [24] due to the replacement of $\mathrm{Ca}^{2+}$ 
ions by smaller $\mathrm{Mg}^{2+}$ ions (The $\mathrm{Mg}$ and $\mathrm{Ca}$ ionic radii are 0.72 and $0.99 \AA$, respectively). The shift to a high degree meant the insertion of $\mathrm{Mg}$ into CDHA structure.

Fig. 2 shows the infrared spectrometers of samples $(0 \mathrm{Mg} 80,5 \mathrm{Mg} 80$, and $5 \mathrm{Mg} 500)$. The FTIR spectra of all dried samples showed the characteristic peaks corresponding to CDHA. The bands at 564 and $603 \mathrm{~cm}^{-1}$ were assigned to the $\mathrm{O}-\mathrm{P}-\mathrm{O}$ bending mode of $\mathrm{PO}_{4}{ }^{3-}$. A weak band near $875 \mathrm{~cm}^{-1}$ was due to $\mathrm{P}-\mathrm{O}(\mathrm{H})$ stretching in the $\mathrm{HPO}_{4}{ }^{2-}$ group typical of nonstoichiometric $\mathrm{HA}$, and it was weaker for the $5 \mathrm{Mg} 80$ sample. When this sample is calcined at $500^{\circ} \mathrm{C}$, the band near $875 \mathrm{~cm}^{-1}$ has practically disappeared. The band at $958 \mathrm{~cm}^{-1}$ corresponded to the symmetric stretching vibration of $\mathrm{P}-\mathrm{O}$. The bands at 1043 and $1122 \mathrm{~cm}^{-1}$ were because of asymmetric $\mathrm{P}-\mathrm{O}$ stretching mode of $\mathrm{PO}_{4}{ }^{3-}$. The broad bands at 1637 and $3438 \mathrm{~cm}^{-1}$ were assigned to absorbed water. The bands at 1421 and $1465 \mathrm{~cm}^{-1}$ were stretching mode of $\mathrm{CO}_{3}{ }^{2-}$, which may incorporate during the reaction in air. $\mathrm{CO}_{2}$ has a very affinity to apatite crystal during the synthesis process. A minor number of hydroxyl groups are present in the undoped and doped structure, according to the proposed chemical formulas.

Table 2. Cell parameters, crystallite sizes, and crystalline degrees $(X c)$ obtained by XRD.

\begin{tabular}{c|c|c|c|c} 
Sample & $\mathrm{a}(\AA)$ & $\mathrm{c}(\AA)$ & Crystallite size $(\AA)$ & $\mathrm{Xc}(\%)$ \\
\hline $0 \mathrm{Mg} 80$ & 8.767 & 6.892 & 257 & 29 \\
\hline $5 \mathrm{Mg} 80$ & 8.625 & 6.878 & 243 & 19 \\
\hline $5 \mathrm{Mg} 500$ & 8.624 & 6.878 & 217 & 12
\end{tabular}

\subsection{Calcined powders.}

The XRD patterns for the calcined powders are illustrated in Fig 3. Calcination of the powders, as shown in fig. 3 indicated the improvement in crystallinity by the resolution of peaks when compared to the as-dried powders in fig. 1. Calcination of the un-doped powder at $850^{\circ} \mathrm{C}$ has indicated, as expected, the formation of HA phase together with the $\beta$-TCP phase.

By the XRD analysis, it was possible to obtain the phase proportion of each group with the Relative Intensity Ratio (RIR) of TCP and HA extracted from Eq 4 and expressed in \%.

$$
R I R_{\beta-T C P}=\frac{I_{\beta-T C P}}{I_{H A}+I_{\beta-T C P}}
$$

Where $\mathrm{I}_{\beta \text { TсP }}$ and $\mathrm{I}_{\mathrm{HA}}$ represent the strongest peaks of each crystalline phase, in which HA was described as $2 \Theta=31.45^{\circ}$ (peak (211)), and $\beta$-TCP was described as $2 \Theta=30.76^{\circ}$ (peak (2 0 10)). RIR $_{\beta T C P}=20 \%$ suggesting, after calcination at $850^{\circ} \mathrm{C}$, a partial $\mathrm{CDHA} \rightarrow \beta$-TCP phase transformation.

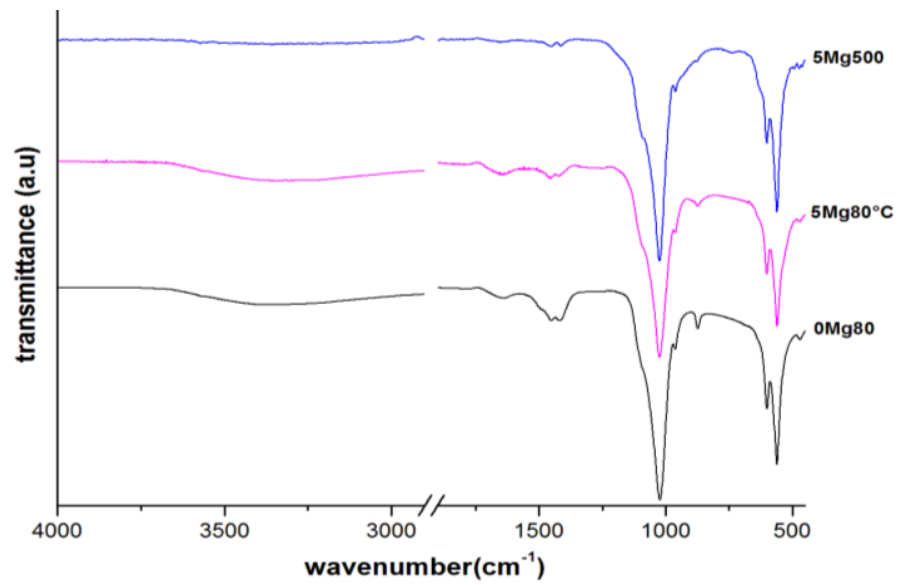

Figure 2. FTIR absorption spectra of $0 \mathrm{Mg} 80,5 \mathrm{Mg} 80$ and $5 \mathrm{Mg} 500$ samples. 


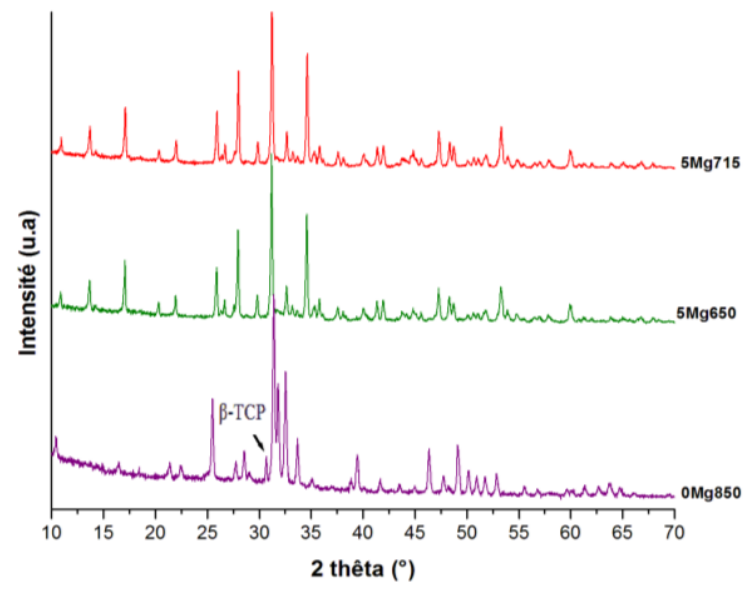

Figure 3. XRD patterns of $0 \mathrm{Mg} 850,5 \mathrm{MG} 650$ and $5 \mathrm{Mg} 715$ samples.

The change from Mg-doped Ca-deficient apatite to $\mathrm{Mg}$ - $\beta$-TCP after heating is observed in fig. 3. All peaks were identified as $\beta$-TCP (JCPDS No. 09-0169). No crystalline HA signals are detected in significant intensity. The sharp and narrow diffraction peaks meant the high crystallinity, and the slight shift to a large degree indicated the incorporation of $\mathrm{Mg}$ into $\beta-$ TCP [25]. No peaks of other phases were observed. Moreover, the refined grain sizes are $39 \pm$ $1 \mathrm{~nm}(0 \mathrm{Mg} 850)$ and $44 \pm 2 \mathrm{~nm}(5 \mathrm{Mg} 715)$ : once $\beta$-TCP is formed, magnesium promotes grain growth. The main phase in the sample changed from HA to Mg-substituted $\beta$-TCP when the $\mathrm{Mg}^{2+}$ was added. $\beta$-TCP is stabilized by the incorporation of $\mathrm{Mg}^{2+}$.

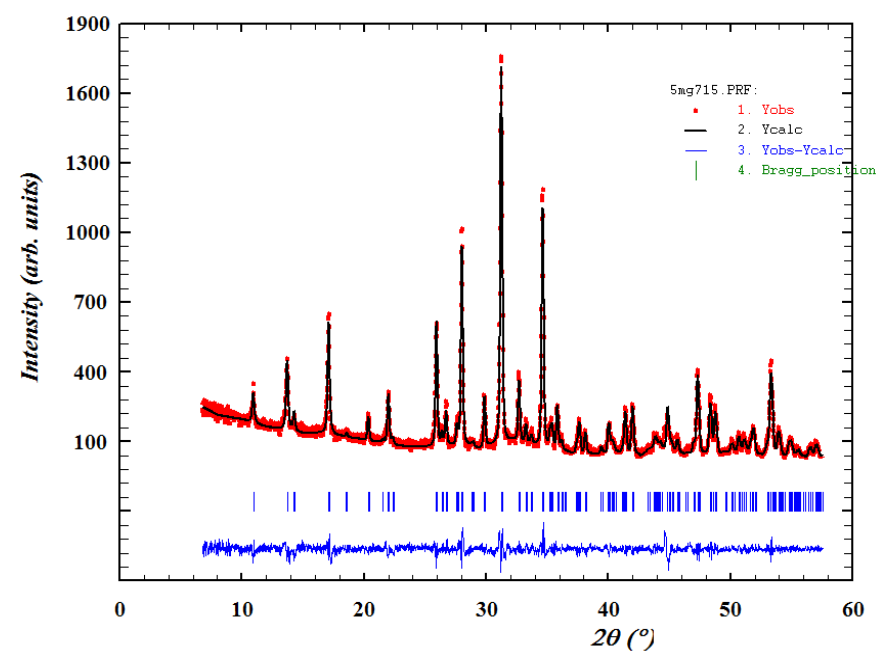

Figure 4. XRD Rietveld refinement patterns of $\mathrm{Mg}-5 \mathrm{~mol} \%$-doped $\beta$-TCP calcined at $715^{\circ} \mathrm{C}(5 \mathrm{Mg} 715$ sample).

The crystalline information of HA and $\beta$-TCP was further analyzed to study the effects of $\mathrm{Mg}^{2+}$ ion substitution on crystal stability. The $\mathrm{Ca}-\mathrm{O}$ coordination numbers for HA crystals (space group $\mathrm{P} 63 / \mathrm{m}, \mathrm{z}=2$ ) are 9 for $\mathrm{Ca}(1)$ and 7 for $\mathrm{Ca}(2)$, respectively. In the presence of $\mathrm{Mg}$, HA favors thermal conversion into $\beta$-TCP. This may because these high coordination numbers made $\mathrm{Mg}-\mathrm{O}$ bonds in the $\mathrm{Mg}-\mathrm{HA}$ lattice extremely unstable [26] as well as the average of $\mathrm{Ca}-$ $\mathrm{O}$ bond distance is around $2.513 \AA$ in HA, which is longer than that in $\beta$-TCP $(2.268-2.287$ $\AA$ ). When $\mathrm{Mg}$ replaces with $\mathrm{Ca}, \mathrm{Mg}-\mathrm{O}$ distance $(2.070-2.084 \AA$ ) is closer to that of $\beta$-TCP $[12,27]$. The transformation from $\mathrm{HA}$ to $\mathrm{Mg}-\beta-\mathrm{TCP}$ can also be explained by that $\mathrm{Mg}^{2+}$ inhibit the crystal growth of HA [28]. Transformation of Ca-deficient apatite to $\beta$-TCP occurs in the temperature region $700-800^{\circ} \mathrm{C}$ [29]. In the presence of $\mathrm{Mg}$, this transformation can be observed when the powder was calcined at a temperature below $650^{\circ} \mathrm{C}$. 
Table 3. Lattice parameters of $5 \mathrm{Mg} 715$ sample.

\begin{tabular}{c|c|c|c} 
Samples & $\mathrm{a}(\AA)$ & $\mathrm{c}(\AA)$ & Cell volume $\left(\AA^{3}\right)$ \\
\hline JCPDS No. 09-0169 & 10.429 & 37.380 & 3520.90 \\
\hline $5 \mathrm{Mg} 715$ & 10.355 & 37.165 & 3451.16
\end{tabular}

Figure 4 shows XRD Rietveld refinement patterns of sample 5Mg715. Yobs represent the experimental data. Ycal represents the calculation strength. Ydif represents the strength difference between experimental data and calculation data, whereas the blue vertical line below the spectrum represents the position of diffraction peak. In the refinement, $X^{2}=1.45, \mathrm{R}_{\mathrm{wp}}=$ $14.5 \%$. The calculated results are in good agreement with the experimental data, which indicates that the Rietveld refinement is accurate. According to the Rietveld refinement, cell parameters of Mg-5 mol\%-doped $\beta$-TCP are $\mathrm{a}=\mathrm{b}=10.355 \AA$ and $\mathrm{c}=37.165 \AA$. Cell parameters of sample $5 \mathrm{Mg} 715$ are shown in Table 3. Compared with standard parameters in JCPDS No.09-0169, it was found that a and c decreased as Mg is incorporated within the TCP structure, as well as cell volume. It may be the result of a smaller ion radius of $\mathrm{Mg}^{2+}$ and proved that $\mathrm{Mg}^{2+}$ was incorporated into $\beta$-TCP crystal.

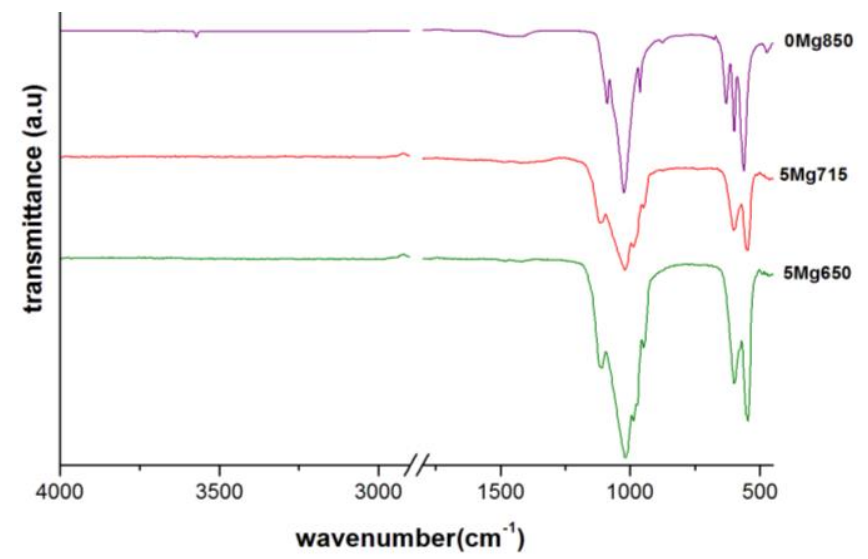

Figure 5. FTIR spectra of $0 \mathrm{Mg} 80,5 \mathrm{Mg} 80$, and $5 \mathrm{Mg} 500$ samples.

Figure 5 shows the FTIR absorption spectra of samples $0 \mathrm{Mg} 850,5 \mathrm{Mg} 650$, and $5 \mathrm{Mg} 715$. The FTIR spectrum obtained from the undoped sample calcined at $850^{\circ} \mathrm{C}(0 \mathrm{Mg} 850)$ showed the presence of phosphate bands observed at 1086 and $1024 \mathrm{~cm}^{-1}, 961 \mathrm{~cm}^{-1}, 600$, and $560 \mathrm{~cm}^{-1}$, and $473 \mathrm{~cm}^{-1}$; hydroxyl bands can be identified at $3560 \mathrm{~cm}^{-1}$, and $632 \mathrm{~cm}^{-1}$. Moreover, the spectrum revealed the presence of the hydrogen phosphate group $\left(\mathrm{HPO}_{4}^{-2}\right)$ band at $877 \mathrm{~cm}^{-}$ ${ }^{1}$. This confirms the formation of biphasic calcium phosphate (biphasic mixtures of HA and $\beta$ -TCP) in the dried powder when calcined at high temperatures. The IR spectra of both $5 \mathrm{~mol} \%$ Mg-DCHA powders calcined at 650 and $715^{\circ} \mathrm{C}$ showed the characteristic peaks corresponding to $\beta$-TCP [30]. No sharp band of $-\mathrm{OH}$ was observed at $3570 \mathrm{~cm}^{-1}$, which demonstrated that no HA generated in the samples.

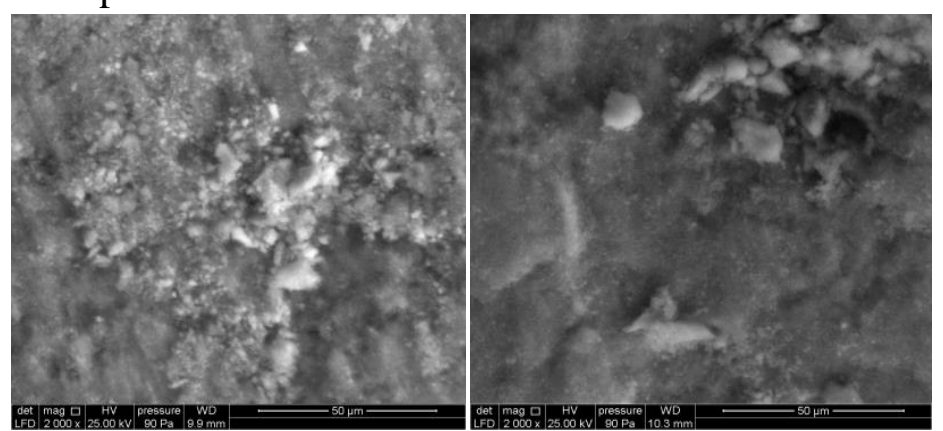

Figure 6. SEM images of undoped sample $0 \mathrm{Mg} 850$ (left) and $5 \mathrm{Mg} 715$ sample (right). 
The results of the SEM analysis are shown in Figure 6. It can be found that both samples are composed of irregular particles with lacking uniformity in both distribution and shape. Regarding the size of the granules, smaller particle size was verified on $\mathrm{Mg} \beta$-TCP (between 280 and $450 \mathrm{~nm}$ ) when compared to dicalcium phosphate granules (between 500 and $850 \mathrm{~nm}$ ) on SEM images.

\section{Conclusions}

Undoped biphasic calcium phosphate nanopowders and 5 mol\% Magnesium-doped TCP nanopowders were successfully produced by precipitation method using $\mathrm{Ca}(\mathrm{OH})_{2}$ and $\mathrm{H}_{3} \mathrm{PO}_{4}$ as the precursors and $\mathrm{MgCl}_{2} .6 \mathrm{H}_{2} \mathrm{O}$ as the source of the dopant. Nanostructured CDHA and $\mathrm{Mg}$-doped CDHA $(\sim 24 \mathrm{~nm})$ with $(\mathrm{Ca}+\mathrm{Mg}) / \mathrm{P}$ ratio equal to 1.54 and 1.52, respectively, were obtained as the first reaction product. Structural changes were observed upon calcining the materials at high temperatures: $80 \%$ of CDHA phase has been converted into HA, and the rest into $\beta$-TCP denotes the formation of biphasic mixtures. Whereas with $\mathrm{Mg}^{2+}$ incorporation in CDHA structure causes lattice contraction and after calcination, the transformation of CDHA into pure $\beta$-TCP occurred at a temperature below $650^{\circ} \mathrm{C}$ by inhibiting the formation of HA crystals.

\section{Funding}

This research received no external funding.

\section{Acknowledgments}

This research has no acknowledgment.

\section{Conflicts of Interest}

The authors declare no conflict of interest.

\section{References}

1. Zou, F.; Zhao, N.; Fu, X.; Diao, J.; Ma, Y.; Cao, X.; Wan, S.; Zhong, S.; Wang, Y. Enhanced osteogenic differentiation and biomineralization in mouse mesenchymal stromal cells on a $\beta$-TCP robocast scaffold modified with collagen nanofibers. RSC Adv. 2016, 6, 23588-23598,https://doi.org/10.1039/C5RA26670J.

2. Jorge E. Rodriguez Chanfrau. Evaluation of the influence of microwave irradiation on a bacterial composed of three phases of calcium phosphates. Biointerface Research in Applied Chemistry 2020, 10, 2, 5141-5144, https://doi.org/10.33263/BRIAC102.141144.

3. Jorge E. Rodriguez Chanfrau, Yaymarilis Veranes Pantoja, Antonio Carlos Guastaldi. Ultrasonic Application and spry drying during amorphous calcium phosphate synthesis. Letters in Applied NanoBionScience 2019, 8, 4, 711-714, https://doi.org/10.33263/LIANBS84.711714.

4. Ke, D.; Bose, S. Doped tricalcium phosphate bone tissue engineering scaffolds using sucrose as template and microwave sintering: enhancement of mechanical and biological properties. Mater Sci Eng C Mater Biol Appl. 2017, 78, 398-404, https://doi.org/10.1016/j.msec.2017.03.167.

5. Tkachenko, S.; Horynová, M., Casas-Luna, M., Diaz-de-la-Torre, S., Dvořák, K.; Celko, L.; Kaiser, J.; Montufar, E.B. Strength and fracture mechanism of iron reinforced tricalcium phosphate cement fabricated by spark plasma sintering J. Mech. Behav. Biomed. Mater. 2018, 81, 16-25, https://doi.org/10.1016/j.jmbbm.2018.02.016.

6. Motisuke, M.; Mestres, G.; Renó, C.O; Carrodeguas, R.G.; Zavaglia, C.A.C.; Ginebra, P. Influence of Si substitution on the reactivity of $\alpha$-tricalcium phosphate. Mater. Sci. Eng. 2017, C 75, 816-821, https://doi.org/10.1016/j.msec.2017.02.099.

7. Altomare, A.; Rizzi, R.; Rossi, M.; El Khouri, A.; Elaatmani, M.; Paterlini, V.; Ventura, G.D.;Capitelli. F. New $\mathrm{Ca}_{2.90}\left(\mathrm{Me}^{2+}\right)_{0.10}\left(\mathrm{PO}_{4}\right)_{2} \beta$-tricalcium Phosphates with $\mathrm{Me}^{2+}=\mathrm{Mn}, \mathrm{Ni}, \mathrm{Cu}$ : Synthesis, Crystal-Chemistry, and Luminescence Properties. Crystals 2019, 9, 288,https://doi.org/10.3390/cryst9060288. 
8. Mayer, I.; Cuisinier, F.J.G.; Gdalya, S.; Popov, I. TEM study of the morphology of $\mathrm{Mn}^{2+}$-doped calcium hydroxyapatite and $\beta$-tricalcium phosphate. J. Inorg. Biochem 2008, 102, 311-317, https://doi.org/10.1016/j.jinorgbio.2007.09.004.

9. Kannan, S.; Lemos, I.A.F.; Rocha, J.H.G.; Ferreira, J.M.F. Synthesis and characterization of magnesium substituted biphasic mixtures of controlled hydroxyapatite/ $\beta$-tricalcium phosphate ratios. J. Solid State Chem 2005, 178, 3190-3196, https://doi.org/10.1016/j.jssc.2005.08.003.

10. Cheng, G.; Deng, C.; Wu, C.; Yin, H.; Ruan, Y.; Sun, Y.; Xie, Q.; Wu, X. Effects of Mn-doping on the structural evolution of b-Tricalcium Phosphate by Rietveld refinement and Raman spectroscopy. Materials Letters 2019, 235, 236-238,https://doi.org/10.1016/j.matlet.2018.10.031.

11. Frasnelli, M.; Sglavo, V.M. Effect of $\mathrm{Mg}^{2+}$ doping on beta-alpha phase transition in tricalcium phosphate (TCP) bioceramics. Acta Biomater 2016, 33, 283-289,https://doi.org/10.1016/j.actbio.2016.01.015.

12. Zhang, M.; Wu, C.; Li, H.; Yuen, J.; Chang, J.; Xiao, Y. Preparation, characterization and in vitro angiogenic capacity of cobalt substituted $\beta$-tricalcium phosphate ceramics. J. Mater. Chem 2012, 22, 2168621694,https://doi.org/10.1039/C2JM34395A.

13. Boanini, E.; Gazzano, M.; Nervi, C.; Chierotti, M.R.; Rubini, K.; Gobetto, R.; Bigi, A. Strontium and Zinc Substitution in $\beta$-Tricalcium Phosphate: An X-ray Diffraction, Solid State NMR and ATR-FTIR Study. $J$. Funct. Biomater 2019, 10, https://doi.org/10.3390/jfb10020020.

14. Sader, M.S.; Martins, V.C.A.; Gomez, S.; LeGeros, R.Z.; Soares, G.A. Production and in vitro characterization of 3D porous scaffolds made of magnesium carbonate apatite (MCA)/anionic collagen using a biomimetic approach. Mater Sci Eng C Mater Biol Appl 2013, 33, 418896,https://doi.org/10.1016/j.msec.2013.06.006.

15. Nabiyouni, M.; Bruckner, T.; Zhou, H.; Gbureck, U.; Bhaduri, S.B. Magnesium-based bioceramics in orthopedic applications. Acta Biomater 2018, 66, 23-43, https://doi.org/10.1016/j.actbio.2017.11.033.

16. Cao, L.; Ullah, I.; Li, N.; Niu, S.; Sun, R.; Xia, D.; Yang, R., Zhang, X. Plasma spray of biofunctional (Mg, Sr)-substituted hydroxyapatite coatings for titanium alloy implants. J. Mater. Sci. Technol 2019, 35, 719726,https://doi.org/10.1016/j.jmst.2018.10.020.

17. Cooke, J.P.; Losordo, D.W. Nitric oxide and angiogenesis. Circulation 2002, 105, 2133-2135.

18. Romani, A.M.P. Beneficial role of $\mathrm{Mg}^{2+}$ in prevention and treatment of hypertension. Int J Hypertens $\mathbf{2 0 1 8 ,}$ 2018, https://doi.org/10.1155/2018/9013721.

19. Gu, Y.; Zhang, J.; Zhang, X.; Liang, G.; Xu, T.; Niu, W. Three-dimensional Printed Mg-Doped $\beta$-TCP Bone Tissue Engineering Scaffolds: Effects of Magnesium Ion Concentration on Osteogenesis and Angiogenesis In Vitro. Tissue Eng Regen Med 2019, 16, 415-429, https://doi.org/10.1007/s13770-019-00192-0.

20. Gallo, M.; Santoni, B.L.G.; Douillard, T.; Zhang, F.; Gremillard, L., Dolder, S., Hofstetter, W., Meille, S., Bohner, M., Chevalier, J., Tadier, S. Effect of grain orientation and magnesium doping on $\beta$-tricalcium phosphate resorption behavior, Acta Biomaterialia 2019, 89, 391-402, https://doi.org/10.1016/j.actbio.2019.02.045.

21. Yang, Y.H.; Liu, C.H.; Liang, Y.H.; Lin, F.H.; Wu, K.C.W. Hollow mesoporous hydroxyapatite nanoparticles with enhanced drug loading and $\mathrm{pH}$-responsive release properties for intracellular drug delivery. J. Mater. Chem. B 2013, 1, 2447-2450, https://doi.org/10.1039/C3TB20365D.

22. Elouahli, A.; Zbair, M.; Anfar, Z.; Ait Ahsaine, H.; Khallok, H.; Chourak, R.; Hatim, Z.Apatitic tricalcium phosphate powder: High sorption capacity of hexavalent chromium removal. Surfaces and Interfaces $\mathbf{2 0 1 8 ,}$ 13, 139-147, https://doi.org/10.1016/j.surfin.2018.09.006.

23. Destainville, A.; Champion, E.; Bernache-Assollant, D.; La Borde, E. Synthesis, characterization and thermal behaviour of apatitic tricalcium phosphate. Mater. Chem. Phys. 2003, 80, 269277,https://doi.org/10.1016/S0254-0584(02)00466-2.

24. Moslim, N.A.; Ahmad, N.; Kasim, S.R.XRD Analysis of Calcined Magnesium Substituted Biphasic Calcium Phosphate (Mg-BCP). J. Phys. Conf. Ser. 2018, 1082 012025. https://doi.org/10.1088/17426596/1082/1/012025.

25. Guo, X.; Long, Y.; Li, W.; Dai, H. Osteogenic effects of magnesium substitution in nanostructured $\beta$ tricalcium phosphate produced by microwave synthesis. J Mater Sci 2019, 54, 1119711212,https://doi.org/10.1007/s10853-019-03674-7.

26. Cui, W.; Song, Q.; Su, H.; Yang, Z.; Yang, R.; Li, N.; Zhang, X. Synergistic effects of Mg-substitution and particle size of chicken eggshells on hydrothermal synthesis of biphasic calcium phosphate nanocrystals. $J$. of Mat Sci \& Tech 2020, 36, 27-36, https://doi.org/10.1016/j.jmst.2019.04.038.

27. Laurencin, D.; Almora-Barrios, N.; de Leeuw, N.H.; Gervais, C.; Bonhomme, C.; Mauri, F.; Chrzanowski, W.; Knowles, J.C.; Newport, R.J.; Wong, A.; Gan, Z.; Smith, M.E. Magnesium incorporation into hydroxyapatite. Biomaterials 2011, 32, 1826-1837,https://doi.org/10.1016/j.biomaterials.2010.11.017.

28. Ding, H.; Pan, H.; Xu, X.; Tang, R. Toward a Detailed Understanding of Magnesium Ions on Hydroxyapatite Crystallization Inhibition. Cryst. Growth Des 2014, 14, 763- 769,https://doi.org/10.1021/cg401619s.

29. Gibson, I.R.; Rehman, I.; Best, S.M.; Bonfield, W. Characterization of the transformation from calciumdeficient apatite to $\beta$-tricalcium phosphate. Journal of Materials Science: Materials in Medicine 2000, 11, 799-804, https://doi.org/10.1023/A:1008905613182. 
30. Massit, M.; Fathi, M.; El Yacoubi, A.; Kholtei, A.; Chafik El Idrissi, B.Effect of physical and chemical parameters on the $\beta$-Tricalcium phosphate synthesized by the wet chemical method. Med. Jour. of Chem 2018, 7, 234-242, http://dx.doi.org/10.13171/mjc7310268-elidrissi. 